\title{
PENGEMBANGAN MODUL ONLINE ZAT ADITIF DENGAN SELF REGULATED LEARNING UNTUK MENINGKATKAN HASIL BELAJAR SISWA
}

\author{
RR. INDAH WAHJU RATNAWATI \\ SMP Negeri 2 Kalitidu, Bojonegoro, Jawa Timur \\ Email : rrindahratnawati@gmail.com
}

\begin{abstract}
ABSTRAK
Penelitian ini bertujuan untuk menghasilkan produk berupa modul online dengan Self Regulated Learning, yang teruji kelayakannya untuk meningkatkan hasil belajar dalam pembelajaran IPA kelas VIII pada materi zat aditif. Jenis penelitian ini adalah Research and Development. Validasi media menggunakan lembar kelayakan yang dikembangkan oleh Pusmenjar. Uji coba media dilakukan 2 kali yang meliputi: uji keterbacaan terbatas terdiri dari 10 siswa dan uji keterbacaan luas yang terdiri dari 32 siswa. Sampel dalam penelitian ini adalah kelas VIII-A sejumlah 32 siswa. Metode yang digunakan dalam penelitian ini adalah diskriptif analitik. Hasil penelitian menunjukkan bahwa penggunaan modul Zat Aditif dengan Self Regulated Learning memiliki validasi conten materi sebesar 91\%, kesesuaian icon SRL 92\%, kesesuian media 90\%, uji terbatas $98 \%$, uji luas $97 \%$, dan nilai $N$-gain sebesar 0,772 masuk dalam kategori tinggi. Ketuntasan klasikal kelas VIII-A dengan menggunakan modul tersebut 97\%. Modul online dengan self regulated learning efektif untuk meningkatkan hasil belajar siswa. Modul online ini tidak hanya berisi informasi, namun didalamnya terdapat arahan, tip dan trik untuk melakukan instruksi, memberikan pilihan strategi, dan ada komunikasi dengan pembaca. Selain itu juga dilengkapi dengan penguatan teori yang telah dipelajari serta contoh soal yang dapat digunakan untuk melatih kemandirian guna meningkatkan hasil belajar.
\end{abstract}

Kata kunci : modul on line, self regulated learning, hasil belajar

\section{PENDAHULUAN}

Pandemi covid-19 telah berdampak pada seluruh bidang kehidupan, tak terkecuali bidang pendidikan. Kegiatan belajar mengajar yang dulu dilaksanakan secara tatap muka saat pandemi lebih dominan dilaksanakan secara online. Kesehatan menjadi faktor yang paling diprioritaskan dari pada bidang-bidang lainnya.

Dalam kehidupan sehari-hari manusia tidak bisa lepas dari alam. Ilmu pengetahuan alam wajib dibelajarkan sejak siswa berada pada jenjang pendidikan dasar. Dalam K-13 jenjang SMP, mata pelajaran Ilmu Pengetahuan Alam merupakan mata pelajaran wajib, dan masuk pada kelompok A. Ilmu Pengetahuan Alam tidak hanya bersifat teori saja, namun penerapnnya dalam kehidupan sehari-hari sangat diperlukan. Salah satunya adalah materi penambahan zat pada makanan atau minuman. Zat yang ditambahkan dalam makanan atau minuman sebagai pengawet, pemanis, perasa, penyedap, pengental disebut dengan zat aditif (Zubaidah, 2017). Ada dampak negative yang ditimbulkan saat manusia mengkonsumsi zat aditif buatan secara berlebihan, karena itulah materi zat aditif penting untuk diketahui siswa sejak di kelas VIII SMP atau MTs..

Di era digital seperti saat ini, siswa merasa lebih bangga, lebih praktis membawa HP dari pada membawa modul cetak. Inilah yang menjadi motivasi untuk membuat modul online. Modul tersebut bisa didownload, kemudian dibaca dimanapun siswa ingin membacanya. Kebanyakan modul yang beredar di sekolah, secara umum hanya berisi teks dan informasi searah, tanpa melibatkan komunikasi dengan pembacanya. Itulah yang menjadi penyebabkan pembaca menjadi cepat bosan, lelah dan mengantuk. Selain itu langkah-langkah eksperimen yang dipaparkan dalam modul atau pun buku teks, kebanyakan hanya berisi perintah. Hal ini sejalan dengan penelitihan terdahulu yang dilakukan oleh Syahrul (2017) pemahaman teks diukur dengan pemahaman melaksanakan perintah atau latihan yang mengarahkan peserta didik dalam memahami struktur, isi atau pesan teks yang dirancang untuk pencapaian KI dan KD. Hal tersebut menunjukkan bahwa siswa hanya dijadikan sebagai obyek, bukan sebagai subyek, 
sehingga tak mengherankan jika siswa enggan membacanya. Hasil akhir yang dijumpai, pesanpesan yang ada di dalam modul tidak bisa tersampaikan secara maksimal, akibatnya banyak siswa yang memperoleh nilai dibawah KKM.

Modul sebagai penunjang kegiatan belajar mengajar disekolah memberikan kontribusi yang signifikan terhadap kemajuan dalam dunia pendidikan. Untuk itu penulis mengembangkan sebuah modul dengan pendekatan Self Regulated Learning sebagai buku pendamping siswa, terutama saat belajar materi Zat Aditif. Perangkat ajar berupa modul yang penulis kembangkan ini sejalan dengan pendapat Zimmerman (dalam Alfina, 2014) yang mendefinisikan self regulated learning sebagai kemampuan pelajar untuk berpartisipasi aktif dalam proses belajarnya, baik secara metakognitif, secara motivasional dan secara behavioral. Sedangkan menurut Yulianti (2016) self regulated learning diartikan sebagai kemampuan diri sendiri dalam mengatur strategi belajar sehingga tercipta efektifitas saat pembelajaran guna mencapai target yang telah ditetapkan. Hal tersebut juga sejalan dengan pemikiran Reni, Kuswandi dan Sihkabuden (2017) self regulated learning merupakan aktifitas belajar yang banyak dikendalikan oleh pelajar sendiri, mulai membuat perencanaan, penyelesaian sampai pada pemantauan dalam menyelesaikan tugas secara baik. Jadi modul Zat aditif dengan self regulated learning merupakan modul yang memberikan keleluasaan kepada siswa untuk berpartisipasi aktif dalam proses belajar, menentukan perencanaan, strategi, tujuan dan mengontrol belajar mereka sendiri, dengan menggunakan sumber belajar dari lingkunagan serta informasi dari pemikiran hasil membaca modul tersebut.

Dari uraian di atas kemampuan self regulated learning (SRL) sangat penting dimiliki oleh siswa agar mereka bisa bertanggung jawab terhadap diri untuk pencapaian tujuan hasil belajar yang ditargetkan.

\section{METODE PENELITIAN}

Penelitian ini dilaksanakan di SMPN 2 Kalitidu pada siswa Kelas VIII- A, sejumlah 32 siswa. Jenis penelitian ini adalah Research and Developmen (penelitian dan pengembangan). Metode penelitian yang digunakan adalah diskriptif analitik. Prosedur penelitian seperti yang tercantum pada gambar di bawah ini.

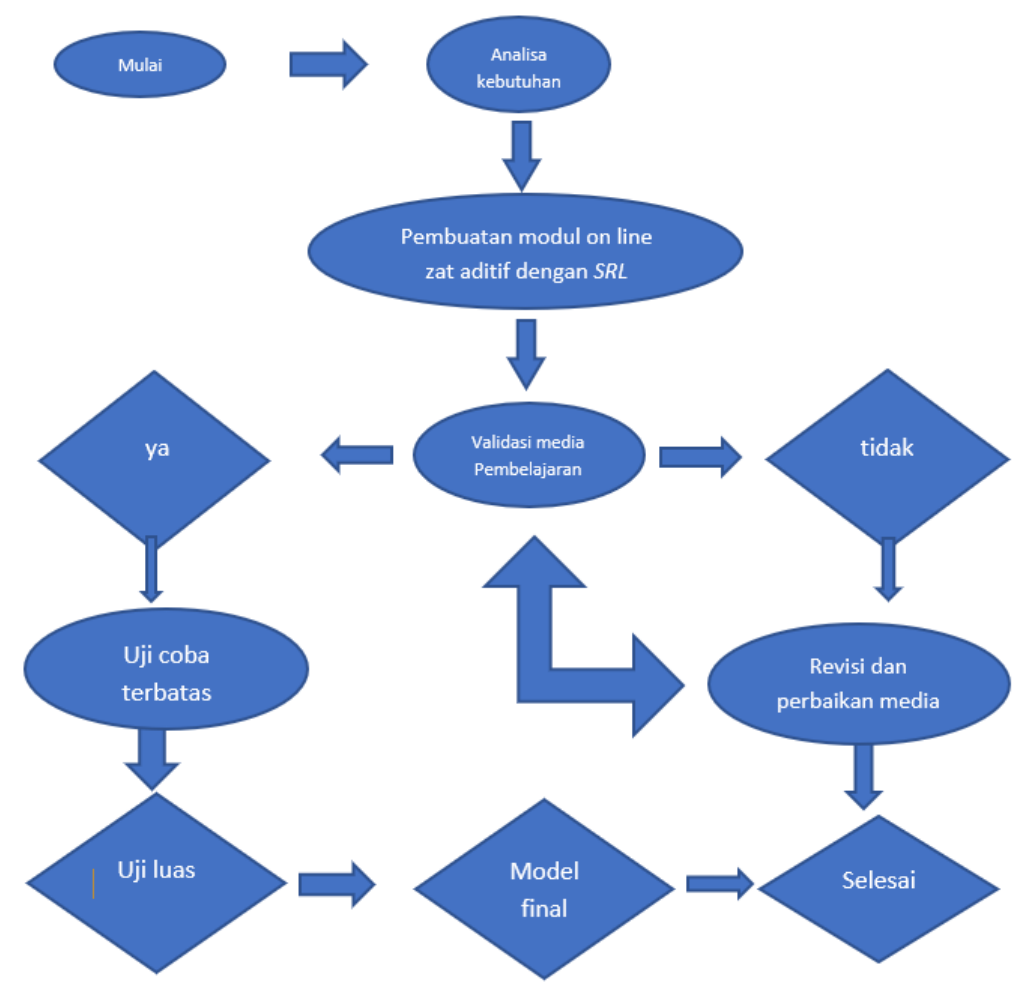

Gambar 1. Diagram flowcad prosedur pengembangan media 
Pengumpulan data dilakukan dengan survey melalui google form, studi pustaka, uji kelayakan media dan nilai $e$-test. Nilai e test diperoleh dari nilai pre tes dan nilai post tes. Survey dengan google form digunakan untuk mengetahui materi apa yang dibutuhkan oleh siswa dan bahan ajar yang bagaimana yang diinginkan siswa.

Studi Pustaka digunakan untuk mendapatkan materi yang akan disusun dalam pembuatan modul. Uji kelayakan meliputi uji keterbacaan modul oleh siswa dan kesesuaian conten dengan materi. Lembar validasi yang digunakan adalah lembar Validasi yang dikembangkan oleh Pusmenjar. Untuk mengetahui peningkatan hasil belajar siswa dilakukan analisis $N$-gain dari nilai pre tes dan post tes siswa.

\section{HASIL DAN PEMBAHASAN}

Penelitian yang termasuk Research and Development ini, pengembangannya mengikuti paparan dari Borg and Gall dalam (Nugroho, Shodiq, Indarti, 2021) dan dipadukan dengan Pedoman Penyusunan modul milik Kemendikbud. Yang menjelaskan bahwa pengembangan dalam penyususunan modul meliputi 5 tahap. Secara garis besar adalah sebagai berikut: 1) pengumpulan, 2) perencanaan, 3) pengembangan, 4) uji coba awal, 5) implementasi pada kegiatan pembelajaran.

Langkah awal sebagai tahap-1 dari penelitian ini adalah melakukan analisis kebutuhan dengan cara pengumpulan informasi pada kompetensi dasar (KD) berapa materi itu dibutuhkan oleh siswa. Hal tersebut dilakukan dengan memberikan quisioner melalui google form untuk diisi siswa. Rumus yang digunakan adalah rumus persentase dari Sugiono, yang secara matematis ditulis sebagai berikut:

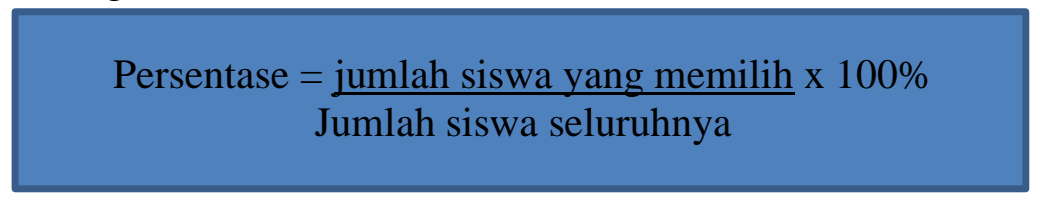

Sugiono (2013)

Hasil survey pada kelas VIII-A yang berjumlah 32, didapatkan data sebagai berikut: $30 \%$ menyatakan mata pelajaran IPA merupakan pelajaran yang menyenangkan, $25 \%$ menyatakan biasa saja dan $45 \%$ menyatakan pelajaran IPA merupakan mata pelajaran yang sulit. Selanjutnya ditanya materi apa yang ingin dipelajari pada mata pelajaran IPA, 23\% menyatakan materi tekanan, 35\% ingin mempelajari materi optik dan sisanya $42 \%$ ingin mempelajari materi zat aditif. Untuk petanyaan materi apa dalam mata pelajaran IPA yang disukai, materi tekanan menempati urutan ketiga sebesar $20 \%$, Zat aditif menempati urutan yang kedua (32\%), dan materi optik menempati urutan pertama sebesar $48 \%$. Sedangkan pada pertanyaan materi apa yang paling sulit dipelajari menurut siswa, materi zat aditif menduduki posisi pertama $62 \%$, materi tekanan berada diposisi kedua $20 \%$ dan materi optic menduduki posisi ke tiga sebesar $18 \%$.

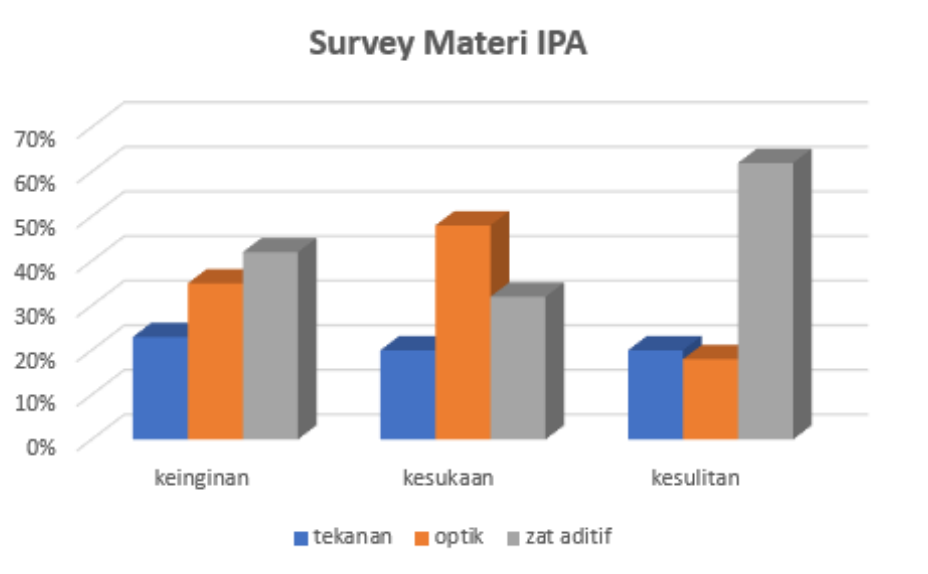

Gambar 2. survey materi dalam mata pelajaran IPA 
Dari gambar tersebut terlihat bahwa materi zat aditif merupakan materi yang sulit dipelajari, namun merupakan materi yang ingin dipelajari tetapi masih kurang disukai oleh siswa. Kemudian dilakukan survey lagi untuk mengetahui bahan ajar yang bagaimana yang dibutuhkan siswa. Yang memilih penggunaan modul on-line dalam pembelajaran zat aditif sebanyak $68 \%$, sedangkan yang memilih menggunakan bahan ajar berupa buku teks cetak sebanyak $32 \%$. Menurut siswa modul onlineitu praktis, bisa dibaca dimanapun, tidak terlalu berat saat membawanya. Dengan pertimbangan tersebut peneliti mengembangkan modul online yang didalamnya dilengkapi dengan sajian gambar untuk mendukung informasi teks yang diberikan serta menarik minat pembaca. Selain itu kemudahan pengoperasian, dan kecepatan penyampaian juga menjadi pertimbangan peneliti dalam mengembangkan modul online ini. Hal tersebut sejalan dengan pendapat (Nugroho, Sodiq \& Indarti, 2021) yang menyatakan bahwa kelebihan e-modul adalah menarik bagi siswa, mudah dibawa kemanamana, dapat dibagikan dengan cara membagikan link s.id dan barcode.

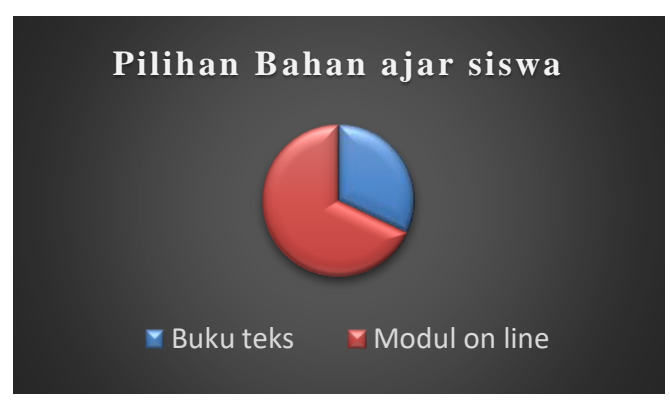

\section{Gambar 3. Pilihan Bahan ajar yang digunakan siswa}

Mengacu pada hasil survey tersebut maka dilanjutkan ke tahap-2 dengan melakukan perencanaan pembuatan modul. Langkah awal yang dilakukan adalah melalui studi Pustaka mengumpulkan materi yang berkaitan dengan zat aditif yang terdapat dalam Kompetensi Dasar 3.5. dan 4.5. Modul online yang peneliti kembangkan ini dilengkapi dengan pendekatan self regulated learning, fungsinya memberikan arahan, strategi yang harus dilakukan, atau pun memberikan motivasi pada siswa yang membacanya. Pada Modul online ini juga dituliskan sumber dari mana conten informasi itu diambil, serta dilengkapi dengan contoh-contoh soal, yang memungkinkan siswa untuk belajar secara mandiri. Hal ini sejalan dengan penelitian yang dilakukan oleh (Ranti, Budianti \& Trisna, 2017) yang mengatakan bahwa kemandirian belajar diartikan sebagai kesadaran siswa untuk belajar, menentukan langkah pembelajaran sendiri, serta melakukan kegiatan evaluasi serta refleksi terhadap apa yang telah dipelajari. Selain itu juga selaras dengan pemikiran (Riana, Farida, Dewi, 2021) yang menjelaskan bahwa dalam belajar membutuhkan ketekunan, ketelitian, kemandirian serta kesabaran dalam mempelajari konsep atau pun memecahkan suatu permasalahan, kemampuan tersebut merupakan salah satu unsur Self Regulated Learning. Hal itulah yang membedakan modul yang dikembangkan ini dengan modul lainnya.

Langkah -langkah pembuatan modul Zat Aditif dengan Self Regulated Learning, dengan cara: Menentukan Kompetensi Dasar sesuai dengan tema yang diangkat. Memperkenalkan Icon Self Regulated Learning (Icon SRL) terdapat komunikasi dengan pembaca sehingga dapat mengurangi kejenuhan siswa saat membaca. 

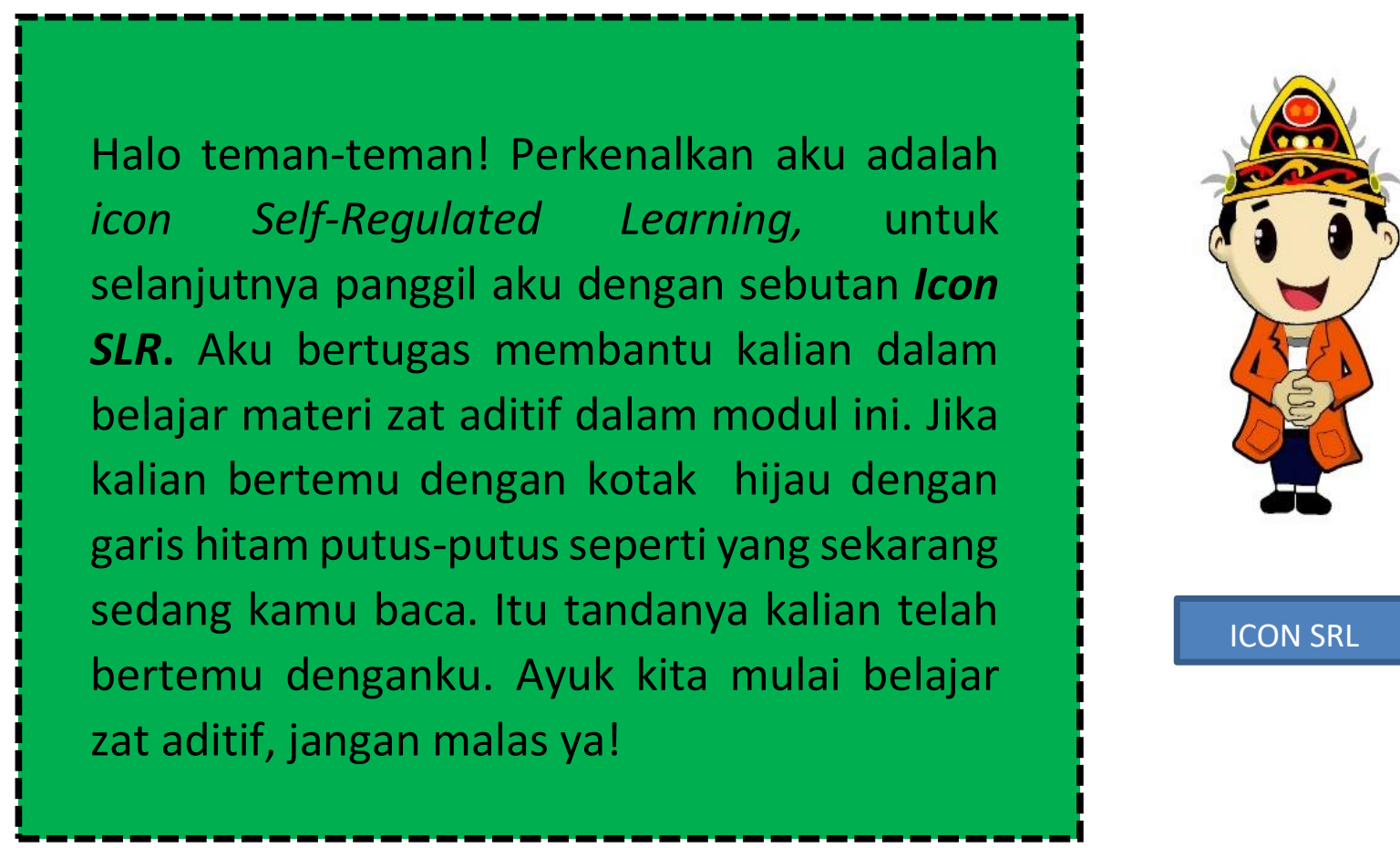

Gambar 4 .Icon $S R \bar{L}$

Langkah selanjutnya adalah membuat petunjuk penting penggunaan modul dan pembuatan peta konsep tentang materi yang akan dipelajari.

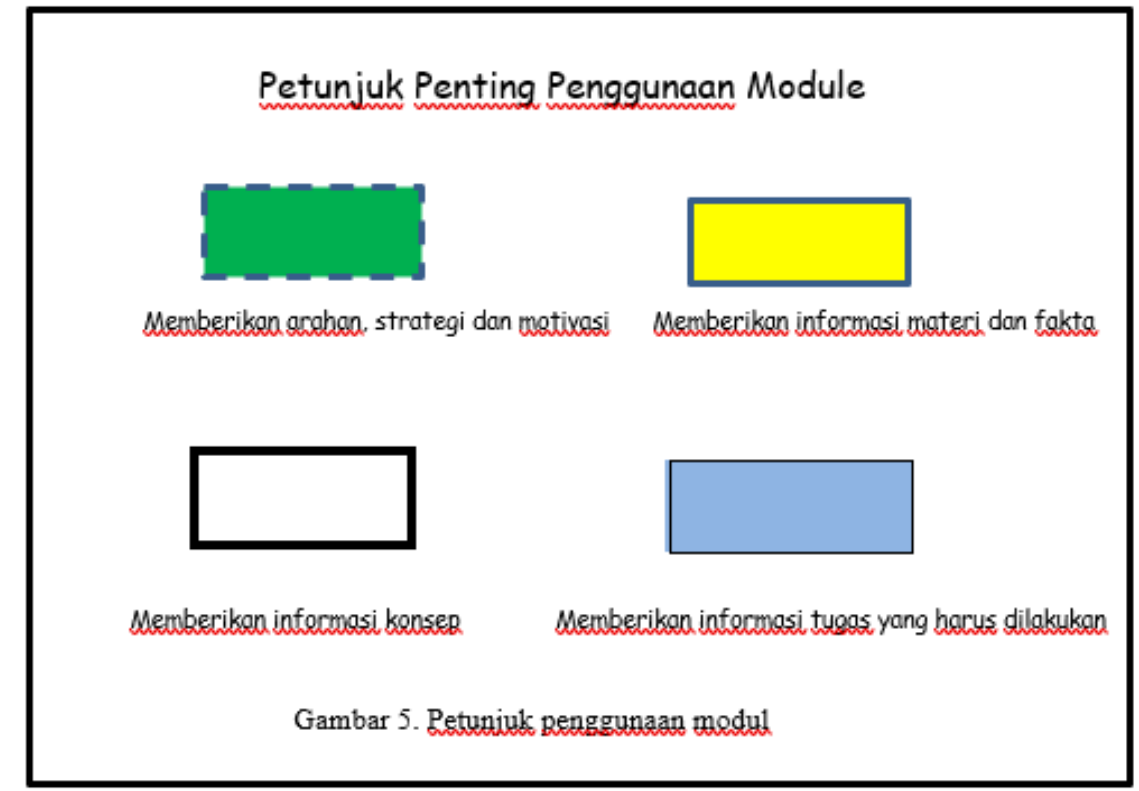

Setelah membuat petunjuk penggunaan modul, Langkah selanjutnya adalah penulisan materi dan pemberikan contoh soal. Kemudian dilanjutkan dengan pemberian latihan soal untuk mengukur pemahaman konsep. Pada bagian penugasan siswa diminta melakukan observasi bahan dilingkungan sekitar yang dapat dijadikan sebagai zat aditif. Pada bagian akhir modul disertakan rangkuman dan daftar pustaka.

Berikut adalah tampilan depan modul Zat Aditif 


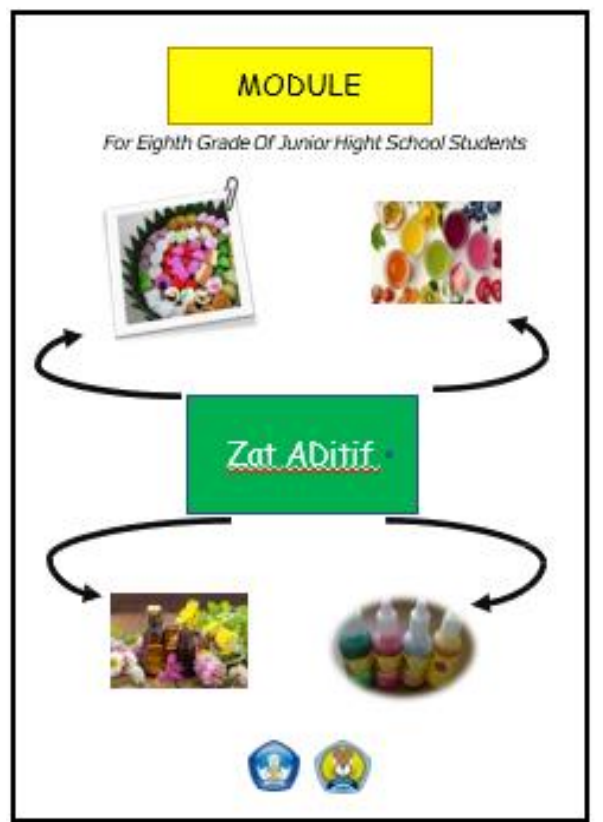

Gambar 6. Sampul modul zat aditif

Struktur isi modul ditampilkan dalam tabel berikut

Tabel 1. Struktur Isi Modul Online Zat Aditif

\begin{tabular}{|l|l|l|}
\hline No. & Bagian modul & Rincian \\
\hline 1. & Sampul & halaman awal \\
\hline 2. & Kata pengantar & ada di bagian i \\
\hline 3. & Petunjuk Penggunaan Modul & Ada di bagian ii \\
\hline 4. & Daftar & Terdiri dari daftar isi, daftar table, daftar gambar \\
\hline 5. & Peta Konsep & Peta konsep zat aditif \\
\hline 6. & Materi & Pengertian, jenis-jenis, contoh \\
\hline 7. & Percobaan & $\begin{array}{l}\text { Percobaan uji boraks, percobaan menetukan zat } \\
\text { aditif alami dan buatan }\end{array}$ \\
\hline 8. & Contoh soal & Contoh soal beserta penyelesaiannya \\
\hline 9. & Evaluasi & Evaluasi pemahaman konsep \\
\hline
\end{tabular}

Validasi kesesuian materi dan kesesuaian Icon SLR dilakukan oleh Bapak Kepala Sekolah pada salah satu SMP Negeri di Bojonegoro yang S2nya di tempuh di Universitas Sebelas Maret Surakarta, jurusan Pendidikan IPA. Hasil persentase Validasi content diperoleh score $91 \%$ termasuk kategori sangat baik. Hasil validasi kesesuaian Icon SRL diperoleh score $92 \%$, dengan kategori sangat baik, dan validasi media gambar dilakukan oleh ahli media dengan persentase perolehan score $90 \%$, kategori sangat baik juga. Uji keterbacaan modul oleh siswa yang meliputi uji terbatas dan uji luas. Uji terbatas terdiri dari 10 siswa, 98\% menyatakan mudah memahami isi modul. Uji luas meliputi seluruh siswa dalam kelas VIII-A yang berjumlah 32 siswa, 97\% menyatakan kebahasaan serta pokok pikiran dalam tiap-tiap halaman modul mudah dipahami. Dari hasil validasi dan uji kelayakan dapat disimpulkan bahwa modul tersebut layak digunakan dalam pembelajaran.

Tabel 1. Hasil Validasi

\begin{tabular}{|c|l|c|c|}
\hline No & Validator & Hasil & Predikat \\
\hline 1 & Ahli Content Materi & $91 \%$ & Sangat Baik \\
\hline
\end{tabular}


Vol 1. No. 3, Juli 2021 P-ISSN : 2774-8030, e-ISSN : 2774-8030

\begin{tabular}{|c|l|c|c|}
\hline 2 & Kesesuaian Icon SRL & $92 \%$ & Sangat Baik \\
\hline 3 & Ahli Media & $90 \%$ & Sangat Baik \\
\hline 4 & $\begin{array}{l}\text { Uji Keterbacaan (uji } \\
\text { terbatas) }\end{array}$ & $98 \%$ & Sangat Baik \\
\hline 5 & Uji Keterbacaan (uji luas) & $97 \%$ & Sangat Baik \\
\hline
\end{tabular}

Dari tabel tersebut dapat dilihat bahwa modul dengan Self Regulated Learning, dapat digunakan tanpa revisi.

Setelah melakukan validasi modul, langkah selanjutnya adalah mengimplementasikan pada proses pembelajaran. Sebelum menggunakan modul siswa diukur kemampuan dasarnya menggunakan pretes. Setelah menggunakan modul pada akhir pembelajaran, diadakan post tes untuk mengetahui peningkatan hasil belajar. Analisis data dilakukan dengan menggunakan rumus $N$-gain. Adapun secara matematis ditulis sebagai berikut:

$$
N \text { Gain }=\frac{\text { Skor Posttest }- \text { Skor Pretest }}{\text { Skor Ideal }- \text { Skor Pretest }}
$$

Gambar 7. rumus $N$-gain

Sumber: Melzer ( 2002) dalam Fadlina , et all, 101,( 2021)

Tabel 2. Pembagian Scor Gain

\begin{tabular}{|c|c|c|}
\hline No. & Nilai $N$-Gain & Kategori \\
\hline 1 & $\mathrm{~g}>0,7$ & Tinggi \\
\hline 2 & $0,3 \leq \mathrm{g} \leq 0,7$ & Sedang \\
\hline 3 & $\mathrm{~g}<0,3$ & Rendah \\
\hline
\end{tabular}

Sumber: Melzer dalam Fadlina , et all, 101, 2021)

Tabel 3. Kategori Efektifitas $N$-gain

\begin{tabular}{|c|c|c|}
\hline No. & Presentase & Tafsiran \\
\hline 1 & $<40$ & Tidak Efektif \\
\hline 2 & $40-55$ & Kurang Efektif \\
\hline 3 & $56-75$ & Cukup Efektif \\
\hline 4 & $>76$ & Efektif \\
\hline
\end{tabular}

Sumber: Hake, R.R (1999)

Setelah menggunakan modul online dengan Self Regulated Learning pada kelas VIII-A diperoleh nilai $N$-Gain 0,769 , nilai presentase $N$-Gain $77 \%$, dan ketuntasan klasikal $97 \%$. Dengan rincian seperti pada tabel 4 di bawah ini.

Tabel 4. Hasil Belajar Siswa Kelas VIII/A

\begin{tabular}{|c|c|c|c|c|c|c|}
\hline No & Kode Siswa & Pre tes & Post tes & $N$-gain & $\% N$-gain & Keterangan \\
\hline 1 & VIII/A/1 & 68 & 90 & 0,6875 & 68 & Tuntas \\
\hline 2 & VIII/A/2 & 50 & 80 & 0,6 & 60 & Tuntas \\
\hline 3 & VIII/A/3 & 45 & 65 & 0,3636364 & 36 & Tidak \\
\hline 4 & VIII/A/4 & 38 & 100 & 1 & 100 & Tuntas \\
\hline 5 & VIII/A/5 & 35 & 90 & 0,8461538 & 85 & Tuntas \\
\hline 6 & VIII/A/6 & 55 & 85 & 0,6666667 & 67 & Tuntas \\
\hline
\end{tabular}


Vol 1. No. 3, Juli 2021 P-ISSN : 2774-8030, e-ISSN : 2774-8030

\begin{tabular}{|c|c|c|c|c|c|c|}
\hline 7 & VIII/A/7 & 58 & 88 & 0,7142857 & 71 & Tuntas \\
\hline 8 & VIII/A/8 & 42 & 95 & 0,9137931 & 91 & Tuntas \\
\hline 9 & VIII/A/9 & 35 & 90 & 0,8461538 & 85 & Tuntas \\
\hline 10 & VIII/A/10 & 30 & 87 & 0,8142857 & 81 & Tuntas \\
\hline 11 & VIII/A/11 & 61 & 96 & 0,8974359 & 90 & Tuntas \\
\hline 12 & VIII/A/12 & 65 & 82 & 0,4857143 & 49 & Tuntas \\
\hline 13 & VIII/A/13 & 59 & 85 & 0,6341463 & 63 & Tuntas \\
\hline 14 & VIII/A/14 & 30 & 97 & 0,9571429 & 96 & Tuntas \\
\hline 15 & VIII/A/15 & 35 & 95 & 0,9230769 & 92 & Tuntas \\
\hline 16 & VIII/A/16 & 30 & 80 & 0,7142857 & 71 & Tuntas \\
\hline 17 & VIII/A/17 & 45 & 80 & 0,6363636 & 64 & Tuntas \\
\hline 18 & VIII/A/18 & 35 & 83 & 0,7384615 & 74 & Tuntas \\
\hline 19 & VIII/A/19 & 25 & 100 & 1 & 100 & Tuntas \\
\hline 20 & VIII/A/20 & 49 & 80 & 0,6078431 & 61 & Tuntas \\
\hline 21 & VIII/A/21 & 44 & 90 & 0,8214286 & 82 & Tuntas \\
\hline 22 & VIII/A/22 & 43 & 85 & 0,7368421 & 74 & Tuntas \\
\hline 23 & VIII/A/23 & 45 & 83 & 0,6909091 & 69 & Tuntas \\
\hline 24 & VIII/A/24 & 44 & 91 & 0,8392857 & 84 & Tuntas \\
\hline 25 & VIII/A/25 & 32 & 85 & 0,7794118 & 78 & Tuntas \\
\hline 26 & VIII/A/26 & 32 & 85 & 0,7794118 & 78 & Tuntas \\
\hline 27 & VIII/A/27 & 44 & 95 & 0,9107143 & 91 & Tuntas \\
\hline 28 & VIII/A/28 & 30 & 90 & 0,8571429 & 86 & Tuntas \\
\hline 29 & VIII/A/29 & 45 & 89 & 0,8 & 80 & Tuntas \\
\hline 30 & VIII/A/30 & 25 & 88 & 0,84 & 84 & Tuntas \\
\hline 31 & VIII/A/31 & 37 & 87 & 0,7936508 & 79 & Tuntas \\
\hline 32 & VIII/A/32 & 50 & 90 & 0,8 & 80 & Tuntas \\
\hline & & & & 0,771742 & 77 & $97 \%$ \\
\hline & & & & & & \\
\hline
\end{tabular}

Dari tabel terlihat bahwa nilai $\mathrm{N}$-Gain 0,772 termasuk dalam kategori tinggi, nilai presentase $\mathrm{N}$-Gain $77 \%$ dan ketuntasan klasikal $97 \%$ menunjukkan bahwa modul online materi zat aditif, dengan Self Regulated Learning tersebut, efektif untuk peningkatan hasil belajar siswa. Hal ini sesuai dengan apa yang diungkapkan oleh Zubaidah (2020) yang menyatakan bahwa dengan Self Regulated Learning, akan timbul suatu dorongan dalam diri seseorang untuk menetapkan tujuan, merencanakan waktu, memecahkan tugas yang lebih besar, mampu mengintrospeksi diri dan mampu merefleksi kinerja guna mengubah strategi manajemen diri agar hasil belajar yang didapatkan menjadi lebih baik. Hasil tersebut juga sejalan dengan penelitian yang dilakukan oleh (Hamonangan \& Widiyanto, 2019; Yulianti, et all, 2016; Miliati, Darwis, \& Asdar, 2018) bahwa Self Regulated Learning yang tinggi, dapat meningkatkan hasil belajar siswa.

Modul dengan pendekatan Self Regulated Learning yang penulis kembangkan untuk meningkatkan hasil belajar siswa ini disajikan secara digital sehingga memudahkan siswa dalam belajar serta mendukung program pemerintah merdeka belajar dan dapat belajar dimana saja. Hasil yang didapat tersebut, juga sesuai dengan penelitian dari (Hilmania \& Desak, 2020) Modul yang dikemas dalam format digital yang biasa disebut modul elektronik atau e-modul efektif untuk menaikkan hasil belajar siswa dan dapat diakses secara online. Hasil penelitian yang penulis lakukan ini juga diperkuat oleh penelitian yang dilakukan oleh (Wahyuni, AS., Warpala, IWS., Agustini, K., 2020) yang menyatakan bahwa hasil belajar yang dicapai siswa dengan menggunakan e-modul berbasis Self Regulated Learning termasuk dalam kategori baik. Dari semua paparan diatas menunjukkan bahwa penggunaan modul online dengan Self Regulated Learning, efektif digunakan untuk meningkatkan hasil belajar siswa.

\section{KESIMPULAN}

Berdasarkan hasil perhitungan statistic analisis data, maka diperoleh kesimpulan sebagai berikut: Pengembangan bahan ajar berbentuk modul onlinedengan self regulated learning memiliki validasi conten materi sebesar 91\%, untuk kesesuaian icon SRL 92\%, Ahli 


\section{CENDEKIA : Jurnal IImu Pengetahuan \\ Vol 1. No. 3, Juli 2021 P-ISSN : 2774-8030, e-ISSN : 2774-8030}

media 90\%, uji terbatas tentang keterbacaan modul 98\%, dan uji luas tentang keterbacaan modul 97\%, dengan kategori sangat baik. Dapat disimpulkan bahwa modul online dengan self regulated learning adalah bahan ajar yang valid. Ini ditandai dengan keputusan expert yakni menyetujui tanpa Revisi.

Modul online dengan self regulated learning efektif untuk meningkatkan hasil belajar siswa, terlihat dari hasil penghitungan statistik nilai $\mathrm{N}$-Gain sebesar 0,772 termasuk dalam kategori tinggi. Bukti efektivitas penggunaan modul terrekam pada lembar kerja dan hasil test yang diselesaikan oleh siswa dengan ketuntasan klasikal sebesar 97\%. Modul online dengan self regulated learning tersebut valid dan layak digunakan dalam pembelajaran guna meningkatkan hasil belajar siswa.

\section{DAFTAR PUSTAKA}

Alfina Irma. (2014)_Hubungan Self Regulated Learning dengan Prokrastinasi Akademik pada Siswa Akselerasi. Psikoborneo. 2 (1), 60-66,

Borg, W.R. \& Gall, M.D. Gall. (1983). Educational Research: An Introduction, Fifth Edition. New York: Longman.

Fadlina, F., Artika, W., Khairil, K., Nurmala, C., \& Abdullah, A. (2021). Penerapan Model Discovery Learning Berbasis STEM pada Materi SistemGerak untuk Meningkatkan Ketrampilan Berfikir Kritis. JPSI Jurnal Pendidikan Sains Indonesia, 9(1), 99-107. doi: 10.24815/jpsi.v9i1.18591

Hake, R. R. (1999). Analyzing Change/Gain Score. American Educational Research Associations Division Measurement and Research Methodology. from http://Lists.Asu.Edu/Egi-Bin....(diakses tanggal 30 Agustus 2021).

Hamongan, R. \& Widiyanto, S. (2019)._Pengaruh Self Regulated Learning dan Self Kontrol terhadap Hasil Bahasa Indonesia. JDPP: Dimensi Pendidikan dan Pembelajaran. 7 (1), $1-10$,

Hilmania, D. \& Desak, P. (2020)._Pengembangan e-modul IPA Bermuatan Tes Online untuk Meningkatkan hasil belajar. JET: Journal of Education Technologi. 4 (1), 73-79, from https://ejournal.undiksha.ac.id/index.php/JET/article/view/24095/14642

Meltzer, D.E. 2002. The relationship between mathematics preparationand conceptual learning gain in physics: a possible inhidden variablei in diagnostic pretest scores. ames:department of physics and astronomy, Lowa State University.

Meiliati, R., Darwis, M., \& Asdar. (2018). Pengaruh Motivasi Belajar, Self Efficacy, dan Sekf Regulated Learning terhadap Hasil Belajar Matematika, Issues in Mathematics Education, 2(1), 83-91,

Nugroho, P., Sodiq, S., \& Indarti, T. (2021). Efektivitas Pengembangan E-Modul Berbentuk OnlineFlipbook pada Materi Aksara Jawa Kelas X SMK. Jurnal Education and Development Institut Pendidikan Tapanuli Selatan, 9(3), 270-275,

Ranti, M., Budianti, I., \& Trisna, N. B., (2017). Pengaruh Kemandirian Belajar (Self Regulated Learning) terhadap Hasil Belajar Mahasiswa pada Mata Kuliah Struktur Aljabar, Math Dedaktic: jurnal Pendidikan Matematika , 3(1), 75-83

Reni, Y., Kuswandi, D., \& Sihkabuden. (2017). Pengaruh Strategi Pembelajaran dan Self Regulated Learning terhadap Hasil Belajar: Kajian dan Riset Dalam Teknologi Pembelajaran published by Department of Educational Technology, Faculty of Education, State University of Malang in collaboration with Indonesian Educational Technology Study Program Association (APS TPI).Inovasi dan teknologi Pendidikan. 4(1). 47- 55,

Sugiono, (2013). Statiska Untuk Penelitian. Bandung: Alfabeta.

Syahrul, A. (2017)._Telaah Buku Teks Pegangan Guru dan Siswa pada Mata Pelajaran Bahasa Indonesia Kelas VII Berbasis Kurikulum 2013. RETORIKA: Jurnal Ilmu Bahasa. 3 (1), $70-82$, 
Wahyuni, AS., Warpala, IWS., \& Agustini, K. (2020). Pengembangan Konten E-Learning Berbasis Self Regulated Learning untuk Meningkatkan Hasil Belajar Airline Reservation, Jurnal Teknologi Pembelajaran Indonesia, 10 (1), 1-12

Yulianti, P., Sano, A., \& Ifdil. (2016). Self Regulated Learning Siswa Dilihat dari Hasil Belajar: Indonesian Institute for Counseling. Education and Therapy Pendidikan Indonesia, 1(2), 98-102, from doi: https://doi.org/10.29210/12016240.

Zimmerman, B.J (1989). Asocial cognitiveview of self-regulated academiclearning. Journal ofeducational psychology, 8 (3), 329.

Zubaidah, S., Dkk. (2007). Ilmu Pengetahuan Alam SMP/MT Semester Satus. Kementerian Pendidikan dan Kebudayaan. Jakarta: Pusat Kurikulum dan Perbukuan, Balitbang,Kemendikbud

.Zubaidah, S. (2020). Self Regulated Learning:Pembelajaran dan Tantagan pada Era Revolusi Industri 4.0, Pendidikan Biologi - Universitas Negeri Malang, Jawa Timur. Retrieved 